\title{
Social factors and teacher performance evaluation in faculties
}

Nebojša Pavlović

\begin{abstract}
Introduction
The Bologna declaration has created numerous issues, but teacher performance evaluation is the most significant one. Namely, the need for job standardization in teaching required evaluating or, simply put, measuring a teacher's performance. This is because the lack of evaluation exerts a significant impact on a teacher's performance (Maksić, 2006). So, we define evaluation as a process in which teachers are analyzed, assessed, and graded according to the set criteria and standards (Robbins I Coutler, 2008; Pavlović, 2015). The Bologna Process requires an accurate assessment of a teacher's performance so as to define clear norms, standards, and procedures in teaching. This part is clear. However, the evaluation led to certain questions. How should it be carried out? Who is competent to assess teachers? How should grades be formed? How are they beneficial for teachers?
\end{abstract}

\section{Methodology}

In this qualitative research, the author collected data through interviews conducted on Google Forms. Teachers working at the five Serbian universities were asked to take part. They described the evaluation model in their faculties, and they provided suggestions on how it should look. A total of 118 participated from all five Serbian universities (from Belgrade, Novi Sad, Niš, Kragujevac, and Novi Pazar). Women accounted for $43.6 \%$ of respondents while men did for $56.4 \%$. Also, there were $24.8 \%$ of professors, $17.5 \%$ of 
associate professors, and $25.4 \%$ of lecturers. In total, $40.3 \%$ work at faculties of social sciences and humanities, $13.3 \%$ at faculties of sciences and mathematics, and $46.4 \%$ at faculties of technology. All of them had the same conditions during the interviews.

\section{Literature Overview}

There aren't many academic papers which deal with the evaluation in the higher educational institutions in Serbia. Only a few papers warn us that this issue isn't taken seriously (Mandić i Vilotijević, 1980; Vilotijević, 1992). Rarely is any information revealed by the faculties. Teachers aren't quick to talk about the evaluation, and usually it all comes down to them saying that the process isn't suitable (Janković \& Jarić, 2009: 5).

\section{Research Results}

In this part of the paper, we have singled out a number of distinctive comments from the teachers. They can serve as the basis for the further research on teacher performance evaluation. In general, comments are similar in how they judge teacher performance evaluation. We didn't change the comments as we wanted to show them as they were submitted.

All teachers mentioned that they needed the evaluation in order to better organize their lectures and adjust them to their students' needs. On the other hand, they said that the evaluation system should be better organized. Here's one belief from an associate professor:

The topic is extremely interesting. It's helpful to see that the evaluation process is taken far more seriously in elementary and high schools than in higher educational institutions. There is a more strict assessment going on in lower educational institutions. (University of $\mathrm{Niš}$ )

This is my comment: I would love clearer criteria for grading and assessing the qualities of teachers - those teaching to undergraduate, masters and $\mathrm{PhD}$ students. Also, I believe that the student evaluations of teachers should have more bearing, and they should be relevant when someone is about to get tenure. (Professor, University of Belgrade)

All teachers exhibited the desire to help improve and change the evaluation process, but it's obvious they're encountering obstacles. Some sugges- 
tions say that students should evaluate their teachers at the end of semesters, and that every grade should be public. Let's take a look at the following comment:

The evaluation should disregard the question of how appealing a subject is. In particular, this is important for those "boring" and "complicated" subjects which students have to attend, although they aren't interested in them. The way a teacher presents their subject can interest students in that topic. Furthermore, the teacher evaluation should be carried out on the final lecture. That's when fewer students are present. Besides, in their first year, students meet a small number of teachers and they evaluate only them. So, they don't have a broader picture that could help them grade a teacher as they should. Additionally, they assess how fair a teacher is without even taking the oral exam. This is why it is perhaps better for students to evaluate their teachers once they graduate. They would be more realistic in their assessments of a teacher's behavior during the exams, and it would dispel any fear they might have of giving bad grades to teachers before exams, regardless of whether the evaluation is anonymous. (Professor, University of Belgrade)

Teachers recognize different types of evaluation and they want to point out the bad sides of the process.

There are different types of the teacher evaluation. The first one was used until last year. According to it, students who attend the lecture and know the teacher are to answer questions on the sheet at the end of the semester. However, the survey is now posted online, and everyone has to respond to it. Students who only take the exam without having any contact with the teacher participate in it. This is used in lectures where there's a larger group of students and itss impossible to take note of who is present and who isn't. Therefore, this model is not good and no one takes it seriously. In contrast, the first one was much better and teachers used to take the grades and answers they received in the survey seriously. For an in-depth research, we should take into consideration the evaluation method itself. (University of Kragujevac)

An assistant professor from the University of Belgrade had a similar comment: 
The biggest issue of the evaluation is the rule that students need to fill in the form when they enroll in a new semester. They do this without giving much thought, and regardless of whether they attended the lecture or not. (University of Belgrade)

One of the most frequent complaints was aimed at the bureaucratic way of carrying out the evaluation. People often wonder whether it's possible for a teacher not to have any evaluation of their pedagogical skills. This is because most teachers haven't taught any pedagogical subject. A teacher organizes a lecture so that it resembles those they had during their time in an elementary or high school.

Since becoming a freshman (in 1972) and up until now (44 years later) no one has come to check whether my teacher or, in this case, myself is delivering a lecture. Never! Because sometimes someone doesn't do it... It seems to me that no one cares about the quality of a lecture! Not even my country that gives me a salary with which I make ends meet nor the staff that hides the real truth. The curriculum ISN'T CONNECTED WITH THE NEEDS OF THE PRACTICE. For years, people have been teaching what they want and think they should. Everyone establishes their own criteria for grading, and sometimes a person "goes crazy" after they fail an exam for the 18th time. And still nothing happens... I tried to do something with my department... they didn't even understand me, so I'm not happy with the results. (Professor, University of Belgrade)

A professor at the University of Niš shares a similar opinion. Apart from bureaucracy, she wonders whether the students are competent to evaluate their teacher. Will the grade help the teacher develop and change their approach?

The evaluation is not properly organized and doesn't make any sense. It is carried out only so that the administration can calculate the score and fill in the report about a teacher before they get an academic title (please note, there is a tendency to write the highest grade no matter what the real one is; no one comments this or checks what someone wrote in their report. No one was ever praised. No one was ever punished for getting a 1 or 2). First of all, I've witnessed students filling in the evaluation recklessly and superficially. They don't even know the teacher. They are giv- 
en the survey so that this part could be done, and, at times, they assess those who aren't their lecturers. Can students really evaluate a teacher like this?! (Professor, University of Niš)

An associate professor from Novi Sad was harsher when it comes to teacher performance evaluation done by students:

My comment is the following: teacher performance evaluation is a nonsense. The sudents are both the judges and the jury. The more lenient you are, the better you appear in their eyes. And the evaluation through the use of SCI form is reckless because a scientist doesn't need to be a good teacher. But this is complicated and should be examined in several dissertations until one finds adequate indicators. (Associate professor, University of Novi Sad)

A higher number of teachers (54.6\%) concluded that an anonymous survey of students was good and necessary. However, they said that certain rules should be introduced:

I think it's good for students to evaluate the work of a teacher, regardless of whether they are competent for that or not. With this in mind, we should select the right questions in the survey. We use a unique survey as ordered by the University of Belgrade, and I wonder whether we should change the questions which are aimed at certain faculties. And one more thing, we should compare the different surveys at the universities and the grades of teachers there. One question that we tend to ask ourselves is how many students should respond to the survey so that it could be valid. Undergraduate studies have larger groups, but masterss programs and vocational subjects (especially elective courses which are taught if at least 5 students enroll) make us wonder whether the survey is valid. (Professor, University of Belgrade)

A certain number of teachers (10.8\%) didn't want anonymous surveys:

Teacher performance evaluation is a good thing. It should and has to exist. In my faculty, students evaluate teachers and the survey is anonymous. I think that it shouldn't be anonymous because why would it be if everything is fair and square? I'm saying this because many teachers are scared to ask a student to leave their exam or sanction them because they use certain resources to pass the exam. They also fear to do anything when a student obstructs 
the lecture, as well as when they come drunk or are rude. Teachers and assistants are scared of the grade because a lower one could mean that they won't get their contracts extended." (University of Belgrade)

\section{Conclusion}

Evaluation is a popular idea. Thinking that only teacher performance evaluation would solve the issue is wrong. We can conclude that this evaluation is one of the weakest parts of the Bologna declaration. Almost all teachers commented on the evaluation process in a negative manner. More than half of the teachers said that the present evaluation model has no significance and that it isn't useful for them. But no one has a concrete suggestion on how that model should look.

\section{Literature}

Janković, Ana and Isidora Jarić. Uslovi rada nastavnog osoblja na univerzitetu u Beogradu: evaluacija rada nastavnika, Filozofija I društvo, 2009.

Maksić, Slavica. Podsticanje kreativnosti u školi, IPI Beograd, 2006.

Mandić, Petar and Mladen Vilotijevič. Vrednovanje rada u školi, Sarajevo: Svjetlost, 1980.

Pavlović, N. Nove uloge menadžmenta ljudskih resursa, Djura Jakšić, Rača, 2015.

Robbins, Stephen and Mary Coutler. Management, Datastatus, Beograd, 2008. Vilotijević, M. Vrednovanje pedagoškog rada u školi, Beograd: Naučna knjiga, 1992. 